\title{
Alternative food and biological control by generalist predatory mites: the case of Amblyseius swirskii
}

\author{
Arne Janssen • Maurice W. Sabelis
}

Published online: 25 March 2015

(C) Springer International Publishing Switzerland 2015

The use of predatory mites for the control of pests has a long history (Huffaker and Spitzer 1951; Huffaker and Kennett 1956; Fleschner 1959; Bravenboer and Dosse 1962), and started at a time when there was still doubt about the regulation of prey populations by predators (Huffaker and Kennett 1956). One of the first attempts of biological control with predatory mites was carried out in strawberry in California, USA, where the generalist predator Neoseiulus reticulatus was released to control cyclamen mites (Huffaker and Kennett 1953, 1956). Generalist predatory mites do not depend on the pest only, but can also use alternative food. It's role in the persistence of predator populations at low pest densities was already acknowledged in these early studies: "A relatively high predator population usually is able to sustain itself for 2 months or more with very low populations of the cyclamen mite. When hungry, these predators have been observed to feed on honeydew, sugar solutions, egg yolk and other liquid foods." (Huffaker and Kennett 1953). This ability to feed on alternative food was not always considered an advantage for biological control, but was taken as a sign of predators not being well adapted to the pest (Huffaker et al. 1969). Nevertheless, several of the early studies already showed that the presence of alternative prey for the predators did not negatively affect biological control, but rather improved it (Huffaker and Kennett 1956; Collyer 1964).

Nevertheless, the emphasis in biological control of greenhouse pests has been on the use of specialist natural enemies for several decades (Encarsia formosa against greenhouse whitefly and Phytoseiulus persimilis against spider mites; Gould 1977). Perhaps this was caused by the long-standing conventional wisdom that biological control was most likely successful when using specialist natural enemies (Doutt and DeBach 1964; Murdoch et al.

In memory of my coauthor, teacher, colleague and dear friend Maurice Sabelis, who sadly did not live to see the appearance of this special issue.

A. Janssen $(\bowtie) \cdot$ M. W. Sabelis

IBED, Section Population Biology, University of Amsterdam, Science Park 904,

1098 XH Amsterdam, The Netherlands

e-mail: arne.janssen@uva.nl 
1985; Parrella et al. 1999; Symondson et al. 2002). Indeed, the majority of successful biological control cases at that time concerned the use of parasitic insects, especially hostspecific species (Beirne 1962). The reasons for not using generalist predators were that (1) they could also target non-pest species (van Lenteren et al. 2003), (2) their dynamics would not be synchronized with the pest, and (3) generalists usually do not have a high potential for increase (Murdoch et al. 1985). Whatever the reasons, the early examples of successful biological control with generalist phytoseiids were picked up not earlier than decades later by Ramakers (1980), Ramakers and van Lieburg (1982) and de Klerk and Ramakers (1986). These authors showed that the phytoseiids Amblyseius barkeri and A. cucumeris can control thrips in greenhouse crops. Moreover, being generalists, these predators could be mass-produced on alternative prey that were cheap and easy to rear (Ramakers and van Lieburg 1982). These predators and other species (e.g., Iphiseius degenerans) can feed and reproduce on sweet pepper pollen, and could therefore be introduced into the flowering crop even before the occurrence of thrips (de Klerk and Ramakers 1986, van Rijn et al. 2002).

Since the pioneering work by Ramakers and colleagues, the use of generalist phytoseiids for pest control has gained a strong foothold; however, the original concerns of using generalist predators remain. Especially the first, predators attacking non-pest species, increased with the growing attention for intraguild predation among natural enemies (Rosenheim et al. 1995), obviously occurring more frequently with generalist predators than with specialists. Evidently, this point needs careful attention, but the occurrence of intraguild predation often does not disrupt biological control (Janssen et al. 2006), and biological control with generalist predators (not only phytoseiid mites) has been successful in many cases. The second concern with using generalist predators, i.e. the lack of synchronization with the pest and the relatively low population growth rate, may actually be advantageous for biocontrol. Synchronization of natural enemies with the pest implies that natural enemy densities will decrease when pest densities are low, and this may facilitate new pest invasions. In contrast, pest outbreaks can be prevented by maintaining populations of generalist natural enemies through the presence of alternative food sources (Collyer 1964; Ramakers 1990; Karban et al. 1994; Hanna et al. 1997; Walde et al. 1997; van Rijn et al. 1999; Nomikou et al. 2002; van Rijn et al. 2002; Liu et al. 2006; Nomikou et al. 2010). The presence of such a standing army of natural enemies also remedies the third objection to using generalists, i.e. that of a lower potential of increase.

Until recently, studies on alternative food for phytoseiid natural enemies mainly considered non-pest foods, such as pollen, nectar or relatively harmless herbivorous arthropods (Bakker and Klein 1992; Hanna et al. 1997; Karban et al. 1997; van Rijn et al. 2002). This changed with the introduction of the predatory mite Amblyseius swirskii. It was collected from the field (Nomikou et al. 2001) and tested for its capacity to control whiteflies (Nomikou et al. 2001, 2002, 2004), and was subsequently found to be able to control thrips as well (Messelink et al. 2006). Further research showed that this generalist can effectively control both pests at the same time (Messelink et al. 2008; Calvo et al. 2011) and has potential to control other pests as well (Wimmer et al. 2008; Arthurs et al. 2009; van Maanen et al. 2010; Park et al. 2010). This has ignited significant interest in this predatory mite, which is increasingly used for biocontrol (estimated at 30,000 ha worldwide; Knapp and van Houten, Pers Comm, 2015), and is currently subject of much research (over 80 publications during the last 6 years, over 50 during the last 3 years; Web of Science ${ }^{\mathrm{TM}}$ ). This special issue, with contributions of authors from two continents, is an attempt to analyse the causes and consequences of the current success of A. swirskii. 


\section{This issue}

The first contribution (Calvo et al. 2015) illustrates that the current success of A. swirskii in Europe was a matter of being at the right place at the right time, and in the right quantities: the predator became commercially available when German consumers demanded Spanish products with fewer pesticide residues. This forced Spanish growers to change from chemical to biological control with this predatory mite in just a few years. Calvo and colleagues also show that the development of a cheap rearing method contributed significantly to the success. In the second paper of this special issue, Hewitt et al. (2015) show that, together with A. swirskii, there is still a role for the predatory mite $N$. cucumeris in controlling thrips in chrysanthemum. This is because $N$. cucumeris is a more cost-effective biological control agent under climate conditions prevalent in this crop during winter. Subsequently, Buitenhuis et al. (2015) review the use of A. swirskii in greenhouse crops in North America, with emphasis on greenhouse ornamentals, and conclude that an important reason for the success of this predator is its capacity to control several pests concurrently.

Although persistence of populations of the generalist $A$. swirskii does not depend on the presence of one pest species, it is still desirable to introduce the predators in the crop before pests occur and supply them with alternative food, especially in ornamentals where economic damage levels are much lower than in vegetable crops. In the fourth contribution to this special issue, Kumar et al. (2015) specifically address the establishment of predator populations in a crop before pest invasions. They identify several pepper cultivars that potentially serve as banker plants for A. swirskii. Along a similar vein, Delisle et al. (2015a, b) assess the suitability of several types of alternative food for A. swirskii and $N$. cucumeris, such as various types of pollen and eggs of the moth Ephestia kuehniella. Apple pollen was the most suitable alternative food, and supplementing A. swirskii with it resulted in better control of western flower thrips on chrysanthemum (Delisle et al. 2015b). Similarly, Leman and Messelink (2015) test various types of alternative food for $A$. swirskii and Amblydromalus limonicus, but they specifically consider the possibility that western flower thrips also benefits from this food (van Rijn et al. 2002). In short-term laboratory experiments, they show that predation of thrips by individual A. swirskii was reduced when pollen was present. However, supplying pollen or eggs of E. kuehniella in a chrysanthemum crop enhanced control of thrips because of the strong numerical response of the predators to the supplied food.

\section{Prospects}

The paper by Leman and Messelink (2015) addresses a potential problem of switching behaviour of generalist predators: when these natural enemies have a strong preference for one food source, populations of less preferred pest species may temporarily escape from predation and cause significant damage. Indeed, thrips did temporarily escape from control by $A$. swirskii when whiteflies are also present in the crop, but good control of both pests was achieved over a longer period of time (Messelink 2012; van Maanen et al. 2012). A relevant question therefore is how to avoid that predators preferentially feed on the supplied food, resulting in temporary increases of pest populations. In our opinion, supplementing predators such as $A$. swirskii with superior alternative food is a viable biological control practice, as several studies have shown (van Rijn et al. 2002; Nomikou et al. 2010; Delisle et al. 2015b; Leman and Messelink 2015). Especially when predators and alternative food are introduced into the crop before pests occur, the densities of the predators will, after some 
time, be limited by the availability of the alternative food. This lack of food will cause the predators to switch to feeding on the pest. Furthermore, predators sometimes perform better on a mixed diet than on single diets (Messelink et al. 2008); hence, they may actually prefer feeding on both alternative food and target prey. A further question is how to supply the alternative food. When alternative food is supplied in pulses with intervals that are relatively long compared to the generation time of the predators, this may result in strong fluctuations in predator densities, and densities of the pests will subsequently also fluctuate (Abrams et al. 1998). Thus, pests may occasionally reach such high densities that damage may exceed economically tolerable levels. Hence, alternative food should probably be added to the crop at intervals that are short relative to the predator's generation time.

In conclusion, the critical attitude towards the use of generalist predators for biological pest control that initially dominated the scientific literature seems to have been countered by examples of excellent control of greenhouse pests by natural enemies such as $A$. swirskii. This does not mean that the original criticism on generalist predators was unfounded. It rather indicates that careful examination of the characteristics of predators and the role of alternative food is needed. The current interest in generalist predators can stimulate such research and help design biological control programs in which the benefits of using generalist predators can be put to practice, while reducing the risks to a minimum. We are convinced that the contributions of this special issue on A. swirskii are an important step in this direction.

Acknowledgments Jan Bruin and Iza Lesna are thanked for their constructive, critical comments.

\section{References}

Abrams PA, Holt RD, Roth JD (1998) Apparent competition or apparent mutualism? Shared predation when populations cycle. Ecology 79:201-212

Arthurs S, McKenzie CL, Chen JJ et al (2009) Evaluation of Neoseiulus cucumeris and Amblyseius swirskii (Acari: Phytoseiidae) as biological control agents of chilli thrips, Scirtothrips dorsalis (Thysanoptera: Thripidae) on pepper. Biol Control 49:91-96. doi:10.1016/j.biocontrol.2009.01.002

Bakker FM, Klein ME (1992) Transtrophic interactions in cassava. Exp Appl Acarol 14:293-311

Beirne BP (1962) Trends in applied biological control of insects. Annu Rev Entomol 7:387-400

Bravenboer L, Dosse G (1962) Phytoseiulus riegeli Dosse als Prädator Einiger Schadmilben aus der Tetranychus urticae-Gruppe. Entomol Exp Appl 5:291-304. doi:10.1111/j.1570-7458.1962.tb00594.x

Buitenhuis R, Murphy G, Shipp L, Scott-Dupree C (2015) Amblyseius swirskii in greenhouse production systems: a floricultural perspective. Exp Appl Acarol (this issue). doi:10.1007/s10493-014-9869-9

Calvo FJ, Bolckmans K, Belda JE (2011) Control of Bemisia tabaci and Frankliniella occidentalis in cucumber by Amblyseius swirskii. Biocontrol 56:185-192

Calvo FJ, Knapp M, van Houten YM, Hoogerbrugge H, Belda JE (2015) Amblyseius swirskii: what made this predatory mite such a successful biocontrol agent? Exp Appl Acarol (this issue). doi:10.1007/ s10493-014-9873-0

Collyer E (1964) The effect of an alternative food supply on the relationship between two Typhlodromus species and Panonychus ulmi (Koch) (Acarina). Entomol Exp Appl 7:120-124

De Klerk M, Ramakers P (1986) Monitoring population densities of the phytoseiid predator Amblyseius cucumeris and its prey after large scale introductions to control Thrips tabaci on sweet pepper. Meded Fac Landbouwwet, Rijksuniv Gent 51:1045-1048

Delisle JF, Brodeur J, Shipp L (2015a) Evaluation of various types of supplemental food for two species of predatory mites, Amblyseius swirskii and Neoseiulus cucumeris (Acari: Phytoseeiidae). Exp Appl Acarol (this issue). doi:10.1007/s10493-014-9862-3

Delisle JF, Shipp L, Brodeur J (2015b) Apple pollen as a supplemental food source for the control of western flower thrips by two predatory mites, Amblyseius swirskii and Neoseiulus cucumeris (Acari: Phytoseiidae), on potted chrysanthemum. Exp Appl Acarol (this issue). doi:10.1007/s10493-014-9863-2

Dosse G (1959) Über einige neue Raubmilbenarten (Acar., Phytoseiidae). Pflanzenschutzber Wien 21:44-61 
Doutt RL, DeBach P (1964) Some biological control concepts and questions. In: DeBach P (ed) Biological control of insect pests and weeds. Chapman and Hall, London, pp 118-142

Flaherty DL, Huffaker CB (1970a) Biological control of Pacific mites and Willamette mites in San Joaquin Valley vineyards. I. Role of Metaseiulus occidentalis. Hilgardia 40:267-308

Flaherty DL, Huffaker CB (1970b) Biological control of Pacific mites and Willamette mites in San Joaquin Valley vineyards. II. Influence of dispersion patterns of Metaseiulus occidentalis. Hilgardia 40:309-330

Fleschner CA (1959) Biological control of insect pests. Science 129:537-544

Gould HJ (1977) Biological control of glasshouse whitefly and red spider mite on tomatoes and cucumbers in England and Wales. Plant Pathol 26:57-60

Hanna R, Wilson LT, Zalom FG, Flaherty DL (1997) Effects of predation and competition on the population dynamics of Tetranychus pacificus on grapevines. J Appl Ecol 34:878-888

Hewitt LC, Shipp L, Buitenhuis R, Scott-Dupree C (2015) Seasonal climatic variations influence the efficacy of predatory mites used for control of western flower thrips in greenhouse ornamental crops. Exp Appl Acarol (this issue). doi:10.1007/s10493-014-9861-4

Huffaker C, Kennett C (1953) Developments toward biological control of cyclamen mite on strawberries in California. J Econ Entomol 46:802-812

Huffaker CB, Kennett C (1956) Experimental studies on predation: predation and cyclamen-mite populations on strawberries in California. Hilgardia 26:191-222

Huffaker CB, Spitzer CH (1951) Data on the natural control of the cyclamen mite on strawberry. J Econ Entomol 44:519-522

Huffaker C, van de Vrie M, McMurtry J (1969) The ecology of tetranychid mites and their natural control. Annu Rev Entomol 14:125-174

Janssen A, Montserrat M, HilleRisLambers R et al (2006) Intraguild predation usually does not disrupt biological control. In: Brodeur J, Boivin G (eds) Trophic and guild interactions in biological control. Springer, Dordrecht, pp 21-44

Karban R, Hougen-Eitzman D, English-Loeb G (1994) Predator-mediated apparent competition between herbivores that feed on grapevines. Oecologia 97:508-511

Karban R, English-Loeb G, Hougen-Eitzman D (1997) Mite vaccinations for sustainable management of spider mites in vineyards. Ecol Appl 7:183-193

Kumar V, Xiao Y, McKenzie CL, Osborne LS (2015) Early establishment of the phytoseiid mite Amblyseius swirskii (Acari: Phytoseiidae) on pepper seedlings in a predator-in-first approach. Exp Appl Acarol (this issue). doi:10.1007/s10493-015-9895-2

Leman A, Messelink G (2015) Supplemental food that supports both predator and pest: a risk for biological control? Exp Appl Acarol (this issue). doi:10.1007/s10493-015-9859-y

Liu C-Z, Yan L, Li H-R, Wang G (2006) Effects of predator-mediated apparent competition on the population dynamics of Tetranychus urticae on apples. Biocontrol 51:453-463

McMurtry J, Huffaker C, Van de Vrie M (1970) Tetranychid enemies: their biological characteristics and the impact of spray practices. II. Tetranychid populations and their possible control by predators: an evaluation. Hilgardia 40:331-389

Messelink GJ (2012) Generalist predators, food web complexities and biological pest control in greenhouse crops. PhD Dissertation, University of Amsterdam

Messelink GJ, van Steenpaal SEF, Ramakers PJM (2006) Evaluation of phytoseiid predators for control of western flower thrips on greenhouse cucumber. Biocontrol 51:753-768

Messelink GJ, van Maanen R, van Steenpaal SEF, Janssen A (2008) Biological control of thrips and whiteflies by a shared predator: two pests are better than one. Biol Control 44:372-379

Murdoch WW, Chesson J, Chesson PL (1985) Biological control in theory and practice. Am Nat 125:344-366

Nomikou M, Janssen A, Schraag R, Sabelis MW (2001) Phytoseiid predators as potential biological control agents for Bemisia tabaci. Exp Appl Acarol 25:271-291

Nomikou M, Janssen A, Schraag R, Sabelis MW (2002) Phytoseiid predators suppress populations of Bemisia tabaci on cucumber plants with alternative food. Exp Appl Acarol 27:57-68

Nomikou M, Janssen A, Schraag R, Sabelis MW (2004) Vulnerability of Bemisia tabaci immatures to phytoseiid predators: consequences for oviposition and influence of alternative food. Entomol Exp Appl 110:95-102

Nomikou M, Sabelis MW, Janssen A (2010) Pollen subsidies promote whitefly control through the numerical response of predatory mites. Biocontrol 55:253-260

Park HH, Shipp L, Buitenhuis R (2010) Predation, development, and oviposition by the predatory mite Amblyseius swirkii (Acari: Phytoseiidae) on tomato russet mite (Acari: Eriophyidae). J Econ Entomol 103:563-569 
Parrella MP, Hansen LS, Van Lenteren JC (1999) Glasshouse environments. In: Bellows TS, Fisher TW (eds) Handbook of biological control: principles and applications of biological control. Academic Press, San Diego, pp 819-839

Ramakers PJM (1980) Biological control of Thrips tabaci (Thysanoptera: Thripidae) with Amblyseius spp. (Acari: Phytoseiidae). Bull SROP/WPRS 1980:203-207

Ramakers PMJ (1990) Manipulation of phytoseiid thrips predators in the absence of thrips. IOBC/WPRS Bull 13:169-172

Ramakers P, van Lieburg M (1982) Start of commercial production and introduction of Amblyseius mckenziei Sch. and Pr. (Acarina: Phytoseiidae) for the control of Thrips tabaci Lind. (Thysanoptera: Thripidae) in glasshouses. Meded Fac Landbouwwet, Rijksuniv Gent 47:541-545

Rosenheim JA, Kaya HK, Ehler LE et al (1995) Intraguild predation among biological control agents: theory and evidence. Biol Control 5:303-335

Shipp L, Elliott D, Gillespie DR, Brodeur J (2007) From chemical to biological control in Canadian greenhouse crops. In: Vincent C, Goettel MS, Lazarovits G (eds) Biological control: a global perspective. CAB International, Wallingford, pp 118-127

Symondson WOC, Sutherland KD, Greenstone MH (2002) Can generalist predators be effective biocontrol agents? Annu Rev Entomol 47:561-594

Van Lenteren JC, Babendreier D, Bigler F et al (2003) Environmental risk assessment of exotic natural enemies used in inundative biological control. Biocontrol 48:3-38

Van Maanen R, Vila E, Sabelis MW, Janssen A (2010) Biological control of broad mites (Polyphagotarsonemus latus) with the generalist predator Amblyseius swirskii. Exp Appl Acarol 52:29-34

Van Maanen R, Messelink GJ, Van Holstein-Saj R et al (2012) Prey temporarily escape from predation in the presence of a second prey species. Ecol Entomol 37:529-535

Van Rijn PCJ, van Houten YM, Sabelis MW (1999) Pollen improves thrips control with predatory mites. Bull IOBC/WPRS 22:209-212

Van Rijn PCJ, van Houten YM, Sabelis MW (2002) How plants benefit from providing food to predators even when it is also edible to herbivores. Ecology 83:2664-2679

Walde SJ, Hardman JM, Magagula CN (1997) Direct and indirect species interactions influencing withinseason dynamics of apple rust mite, Aculus schlechtendali (Acari: Eriophyidae). Exp Appl Acarol 21:587-614

Wimmer D, Hoffmann D, Schausberger P (2008) Prey suitability of western flower thrips, Frankliniella occidentalis, and onion thrips, Thrips tabaci, for the predatory mite Amblyseius swirskii. Biocontrol Sci Technol 18:541-550 